\title{
Characterization of a L-serine dehydratase activity from Streptococcus faecalis
}

\author{
Marta E. FARIAS *, Ana M. STRASSER de SAAD **, \\ Aída A. PESCE de RUIZ HOLGADO **, and G. OLIVER **
}

CERELA, Centro de Referencia para Lactobacilos, Chacabuco 145, 4000 Tucumán, Argentina and Facultad de Bioquímica, Química y Farmacia, Universidad Nacional de Tucumán, Argentina

\section{Summary}

Streptococcus faecalis sp. produces pyruvate and ammonia from L-serine via a specific L-serine dehydratase. The apparent. Michaelis. constant for L-serine is $50 \mathrm{mM}$ and the Vmax is $142 \mathrm{nmol}$ of pyruvate formed per minute and per $\mathrm{mg}$ of protein. Maximum enzymatic activity is observed at $40{ }^{\circ} \mathrm{C}$ and $\mathrm{pH} 8$ in $100 \mathrm{mM}$ phosphate buffer. L-serine is the sole substrate. D-serine, L-threonine and glycine are competitive inhibitors, L-cysteine acts as a non-competitive inhibitor.

The enzyme seems to be a very labile protein ; it is inactivated by dilution, dialysis and temperature. Pyridoxal phosphate is not required for maximum activity.

L-serine dehydratase is strongly inhibited by $\mathrm{Cu}^{2+}, \mathrm{Zn}^{2+}, \mathrm{Hg}^{2+}$, p-chloromercuribenzoate, Tris, borate and acetate. The enzymatic activity is stimulated by $\mathrm{Fe}^{2+}$ ions.

Key words: Streptococcus faecalis - L-serine dehydratase - Serine catabolism.

\section{Résumé}

Caractérisation d'une activité L-sérine déshydratase de Streptococcus faecalis

Streptococcus faecalis sp. produit du pyruvate et de l'ammoniac par une L-sérine déshydratase spécifique, à partir de L-sérine.

La constante apparente de Michaelis pour la L-sérine est de $50 \mathrm{mM}$ et la vitesse maximum de 142 nmoles de pyruvate formé par minute et par $\mathrm{mg}$ de protéine. L'activité enzymatique est maximum à $40^{\circ} \mathrm{C}$ et à $\mathrm{pH} 8$ dans du tampon phosphate $100 \mathrm{mM}$.

La L-sérine est le seul substrat de la réaction. La D-sérine, la L-thréonine et la glycine sont des inhibiteurs compétitifs. La L-cystéine est un inhibiteur non-compétitif.

\footnotetext{
* Fellow of the Consejo Nacional de Investigaciones Científicas y Técnicas (CONICET), Argentina.

** Career Investigator of Consejo Nacional de Investigaciones Científicas y Técnicas (CONICET), Argentina.
} 
L'enzyme semble être une protéine très labile; elle est inactivée par dilution, dialyse et par la température.

Le pyridoxal phosphate n'est pas exigé pour obtenir une activité maximum.

La L-sérine déshydratase est fortement inhibée par les ions $\mathrm{Cu}^{2+}, \mathrm{Zn}^{2+}$ et $\mathrm{Hg}^{2+}$ et par le P-chloromercuribenzoate. L'activité est aussi inhibée par les tampons Tris, borate et acétate.

L'ion $\mathrm{Fe}^{2+}$ a un effet stimulant sur l'activité enzymatique.

Mots-clés : Streptococcus faecalis - L-sérine déshydratase - Catabolisme de la sérine.

\section{Introduction}

Among the microorganisms which play a role in cheese ripening, the enterococci and specially Streptococcus faecalis are involved. Their importance has been shown in manufacture of soft Italian, Cheddar and some Swiss cheeses. This species is found in natural cheese or it is introduced as starter cultures (KosikowsKI, 1978). Although other aspects of their metabolism and its effect on the appearance of flavor constituents is poorly understood. Ammonia is, according to Dumont and ADDA (1978) the only volatile amine to play a genuine role in cheese flavoring, and this compound is produced by $S$. faecalis sp. from L-serine.

The enzymatic, non oxidative deamination of L-serine to pyruvate and ammonia by microorganisms has been known since 1938 (GALE and STEPHENSON, 1938). L-serine dehydratase and L-threonine dehydratase had long been considered to be the same enzyme. However, since the work of BENZIMAN et al. (1960) and CARTer and SAGERS (1972), who proved the existence of a Lserine dehydratase specific for L-serine in Clostridium acidiurici, similar activities have been reported in extracts of other microorganisms, such as Arthrobacter globiformis (BRIDGELAND and JoNES, 1965; GANNON et al., 1977), Escherichia coli $\mathrm{K}_{12}$ (Isenberg and Newman, 1974), Bacillus cereus, Salmonella typhimurium (RAsko et al., 1969), Pseudomonas cepacia (WONG and Lessie, 1979), Bacillus alvei (GRIFFITHS and DE Moss, 1970), Corynebacterium sp. (MoRIKAWa et al., 1974), Klebsiella aerogenes (VINING and MAGASANIK, 1981), and Brevibacterium linens (Hamouy, 1983). The existence of the enzyme in the Genus Lactobacillus, has been demonstrated in a prior work (FARIAS et al., 1985) in Lactobacillus murinus ATCC 35020. In Streptococcus, on the other hand, the existence of this enzyme has not yet been demonstrated. The present paper described the general properties of the L-serine dehydratase from Streptococcus faecalis sp.

\section{Materials and methods}

\section{A. Organism and culture medium}

The strain utilized was Streptococcus faecalis sp. isolated from digestive human tract. CRL 663. 
The culture medium (LAPTg 10 ) was described by RaIBAud et al. (1956) (glucose, $10 \mathrm{~g}$; yeast extract, $10 \mathrm{~g}$; peptone, $15 \mathrm{~g}$; tryptone, $10 \mathrm{~g}$; Tween 80 , $1 \mathrm{ml}$; distilled water, $900 \mathrm{ml}$ ). The $\mathrm{pH}$ was adjusted to 6.5 with $0.2 \mathrm{~N} \mathrm{NaOH}$. The medium was sterilized by autoclaving for $20 \mathrm{~min}$ at $120^{\circ} \mathrm{C}$.

\section{B. Preparation of cell-free extract}

The cells of $S$. faecalis, grown in $2.000 \mathrm{ml}$ of LAPTg medium at $37^{\circ} \mathrm{C}$ were harvested, after $8 \mathrm{~h}$, by centrifugation at $7.000 \mathrm{~g}$ for $15 \mathrm{~min}$ at $4{ }^{\circ} \mathrm{C}$. The pellet was washed twice in $0.1 \% \beta$-mercaptoethanol, then, resuspended in $100 \mathrm{mM}$ potassium phosphate buffer to $40 \%(\mathrm{w} / \mathrm{v})$ and disrupted in a Frenchpress. The cell-free extract was obtained by centrifugation at $30.000 \mathrm{~g}$ for $30 \mathrm{~min}$, at $4{ }^{\circ} \mathrm{C}$.

\section{Enzyme Assay}

Reaction mixtures (final volume of $2 \mathrm{ml}$ ) containing $100 \mathrm{mM} \mathrm{L}$-serine ; $100 \mathrm{mM}$ potassium phosphate buffer $\mathrm{pH} 8$ and $0.1 \mathrm{ml}$ cell-free extract, were incubated at $40{ }^{\circ} \mathrm{C}$. The reaction was stopped by rapidly pipetting $100 \mu \mathrm{l}$ aliquots into $500 \mu \mathrm{l}$ of $10 \%$ (w/v) Trichloroacetic acid (TCA). L-serine dehydratase activity was determined by assaying the pyruvate produced by the method of Friedemann and Haugen (1943).

The mixture was held in an ice bath for $30 \mathrm{~min}$ and was then centrifugated at $5,000 \mathrm{~g}$ for $10 \mathrm{~min}$ at $4{ }^{\circ} \mathrm{C}$. $500 \mu \mathrm{l}$ of $0.1 \%$ (w/v) 2-4-dinitrophenylhydrazine (DNPH) in $2 \mathrm{~N} \mathrm{HCl}$ were added to $500 \mu \mathrm{l}$ of supernatant. After $5 \mathrm{~min}$ at ambiant temperature, $2.5 \mathrm{ml}$ of $2 \mathrm{~N} \mathrm{NaOH}$ were added and the absorbance at $540 \mathrm{~nm}$ was measured.

Specific activity of L-serine dehydratase is expressed as nmoles of pyruvate formed per minute per milligram of protein. The protein concentration was determined by the method of Lowry et al. (1951) with bovine serum albumin as a standard.

\section{Results}

\section{A. Kinetics parameters and specificity of L-serine dehydratase}

L-serine dehydratase activity was detected in cell-free extracts of Streptococcus faecalis grown in LAPTg medium.

The quantity of pyruvate formed was proportional to protein concentration used. In the presence of $100 \mathrm{mM} \mathrm{L}$-serine and $1 \mathrm{mg}$ of protein, pyruvate formation was linear for $20 \mathrm{~min}$.

The rate of enzyme activity was studied as a function of L-serine concentration at $40{ }^{\circ} \mathrm{C}$ and $\mathrm{pH} 8$. From the Lineweaver-Burk curve (fig. 1), the following values were calculated : apparent $\mathrm{Km}$ for L-serine $50 \mathrm{mM}$ and $\mathrm{Vm}$ for L-serine deamination $142 \mathrm{nmol} \cdot \mathrm{min}^{-1}$ per $\mathrm{mg}$ of protein. 


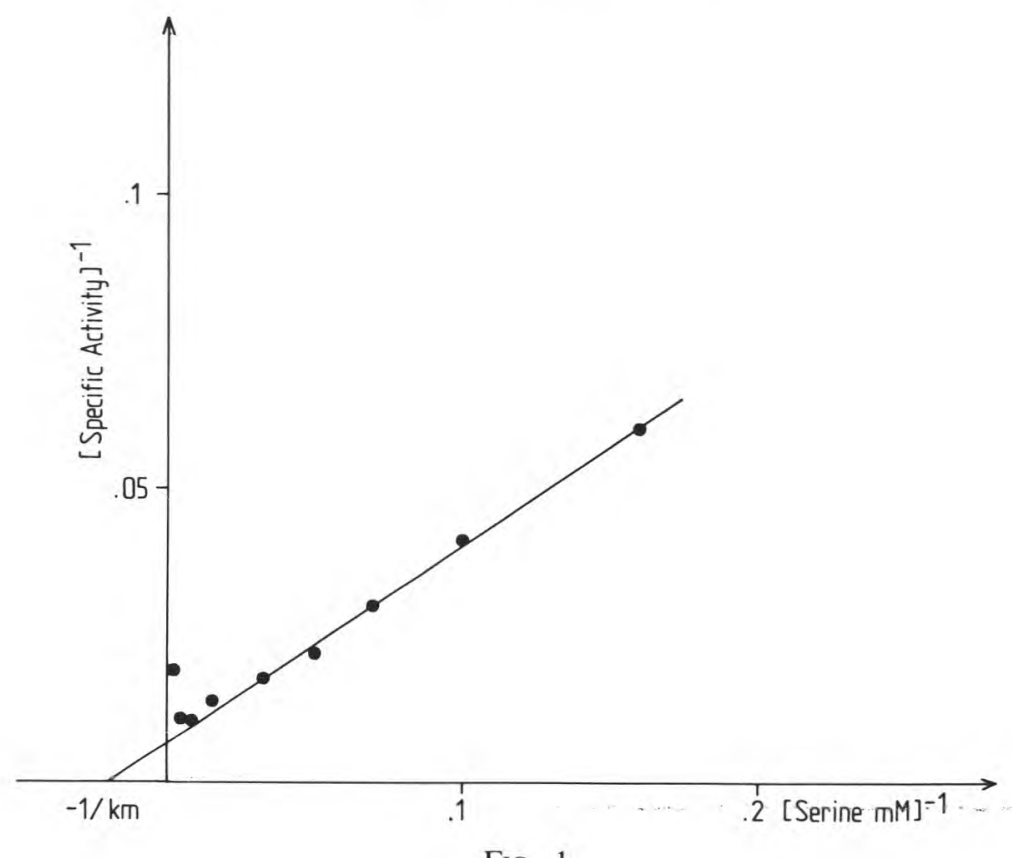

FIG. 1

Graphic determination (Lineweaver-Burk) of kinetic constants of L-serine dehydratase activity.

Détermination graphique (Lineweaver-Burk) des constantes cinétiques de la L-sérine déshydratase.

Pyruvate was not produced when D-serine or L-threonine were added to the reaction mixtures in the absence of L-serine.

The enzymatic activity was not modified by the presence of exogenous pyridoxal-5'-phosphate (PLP).

\section{B. Effect of $\mathrm{pH}$ and temperature}

Enzymatic activity was optimal at pH 8 in $100 \mathrm{mM}$ phosphate buffer. For the test of activity at acid or alcaline $\mathrm{pH}$ values, it was not possible to use acetate, Tris or Borate buffers, since they inhibited the enzymatic activity. From Dixon plot (fig. 2) the following pK values were calculated, for the free enzyme : $\mathrm{pK}_{\mathrm{a}} 7.05$ and $\mathrm{pK}_{\mathrm{b}} 8.5$, and the $\mathrm{pK}$ of the ES complex 6.65.

Pyruvate production was maximal at $40{ }^{\circ} \mathrm{C}$ (fig. 3). The apparent activation energy of the reaction, $\Delta \mathrm{G}^{*}$, was calculated from Arrhenius plot and found to be about $13.200 \mathrm{cal} \mathrm{mol}^{-1}$ (inset fig. 3).

Thermostability was investigated by preincubation of cell-free extract for 10,20 and $30 \mathrm{~min}$ at different temperatures before the rate of enzymatic activity was assayed. 


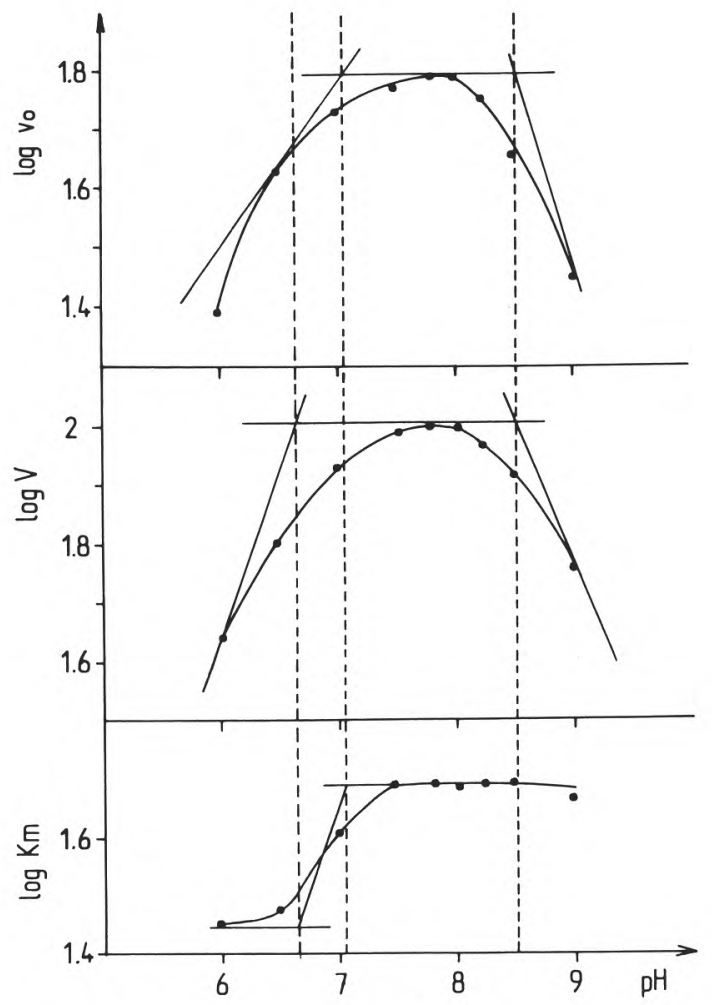

FIG. 2

Effect of $p H$ on $\mathrm{Km}, V$ and vo, for L-serine dehydratase activity.

Effet du pH sur Km, $V$ et vo, pour l'activité L-sérine déshydratase.

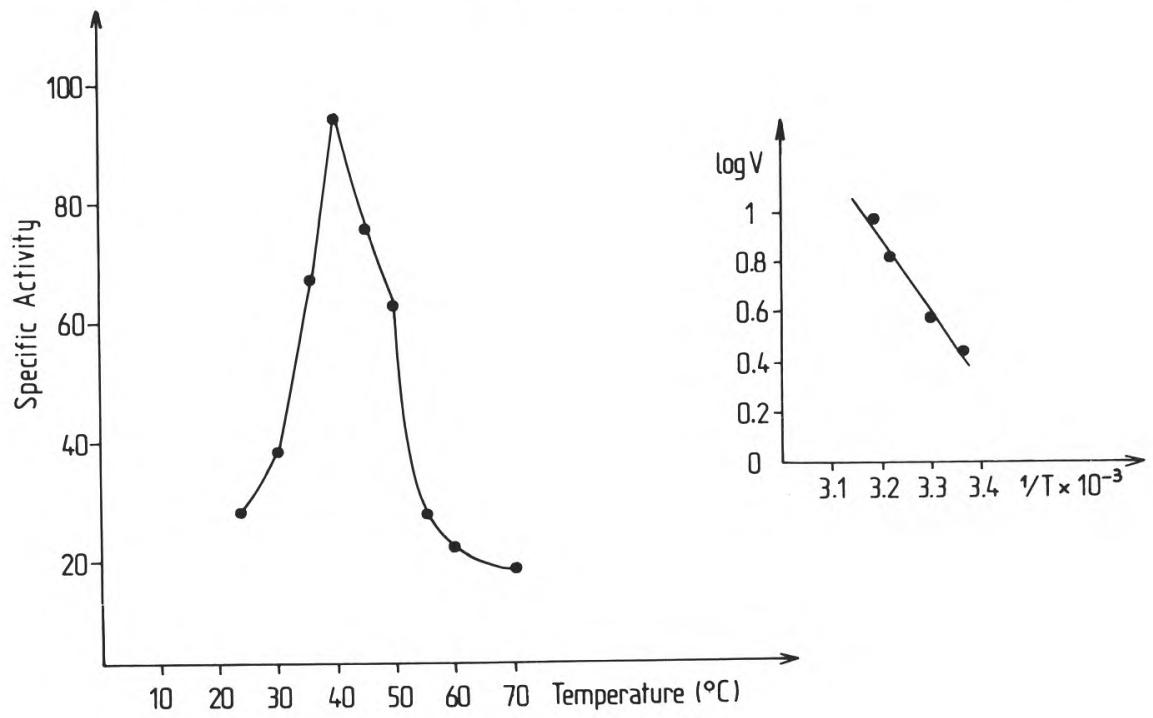

FIG. 3

Effect of temperature on L-serine dehydratase activity. Inset figure: Arrhenius plot. Effet de la température sur l'activité L-sérine déshydratase. 
The results in figure 4 shown a notable loss of activity from $30{ }^{\circ} \mathrm{C}(30 \%$ in $10 \mathrm{~min}$ ). This effect was not observed when the enzymic preparation was preincubated in the presence of $100 \mathrm{mM}$ L-serine. At $60{ }^{\circ} \mathrm{C}$ the activity was only $10 \%$ of the original, while at $70{ }^{\circ} \mathrm{C}$, the enzyme was completely inactive.

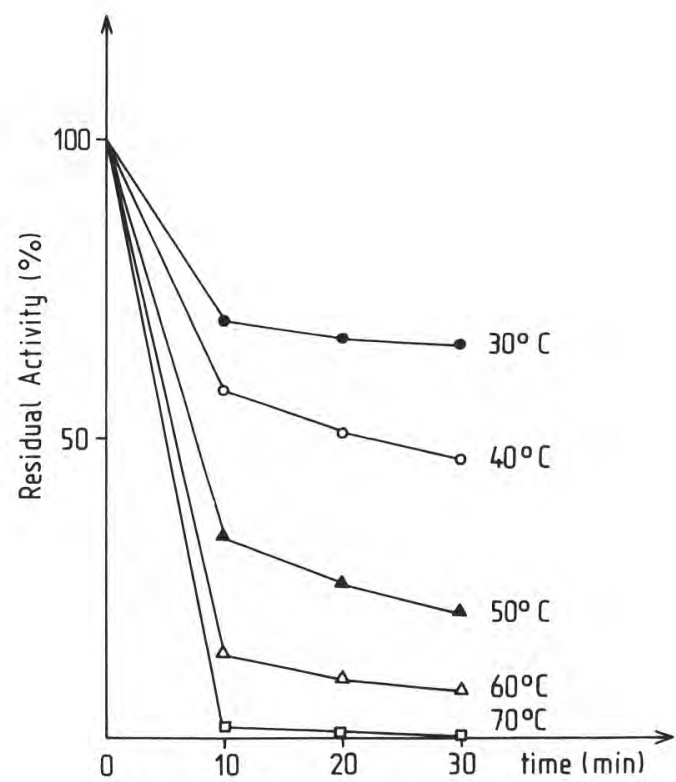

FIG. 4

Thermostability of L-serine dehydratase activity.

Stabilité thermique de l'activité L-sérine déshydratase.

\section{Stability}

When the cell-free extract was dialysed against $100 \mathrm{mM}$ phosphate buffer, $\mathrm{pH} 8$, for $6 \mathrm{~h}$ at $4{ }^{\circ} \mathrm{C}$, a rapid loss of activity was observed $(95 \%)$. Different substances were added to the buffer to prevent the inhibition caused by dialysis. No protection was observed by $10 \mathrm{mM}$ L-cysteine, $\beta$-mercaptoethanol or dithiothreitol. Thermal stability was studied by following the L-serine dehydratase activity during storage at different temperatures (fig. 5).

The half-life of the enzyme at $4{ }^{\circ} \mathrm{C}$ was approximately $24 \mathrm{~h}$. At 0 and $-20{ }^{\circ} \mathrm{C}$, after 3 days, the activity was only 10 and $35 \%$, respectively. No protection was observed by $10 \mathrm{mM}$ dithiothreitol or glutathion (reduced form). At $-70{ }^{\circ} \mathrm{C}$, the enzyme retained $100 \%$ of the original activity after 90 days storage. 


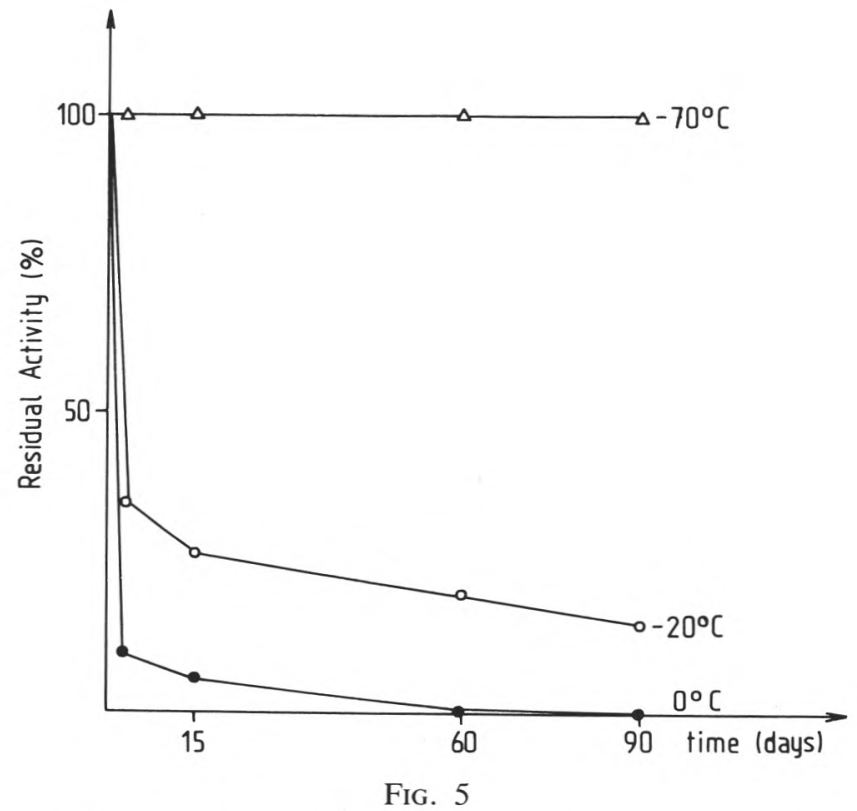

Stability of L-serine dehydratase activity during storage.

Stabilité de l'activité L-sérine déshydratase pendant la conservation.

TABLE 1

Effect of cations on L-serine dehydratase activity Effet des cations sur l'activité L-sérine déshydratase

\begin{tabular}{c|c|c}
\hline \multirow{2}{*}{ Cation (1 mM) } & \multicolumn{2}{|c}{ Specific activity ${ }^{(a)}$} \\
\cline { 2 - 3 } & Before dialysis & After dialysis \\
\hline- & 112 & 6 \\
$\mathrm{Fe}^{2+}$ & 136 & 6 \\
$\mathrm{Fe}^{3+}$ & 113 & 5 \\
$\mathrm{Mg}^{2+}$ & 109 & 6 \\
$\mathrm{Mn}^{2+}$ & 92 & 13 \\
$\mathrm{Zn}^{2+}$ & 74 & 0 \\
$\mathrm{Cu}^{2+}$ & 68 & 0 \\
$\mathrm{Hg}^{2+}$ & 10 & 0 \\
$\mathrm{Fe}^{2+}+\mathrm{DTT}^{(\mathrm{b})}$ & 110 & 20 \\
\hline
\end{tabular}

(a) nmoles of pyruvate/min/mg of protein.

(b) dithiothreitol. 


\section{Effect of cations and substrate analogues}

The results in Table 1 shown the effect of cations on enzymatic activity. In non dialysed cell-free extract, these results do not take into account the concentration of inorganic ions in the preparation which were not determined. Among the cations tested, only $\mathrm{Fe}^{2+}$ stimulate the enzymatic activity. $\mathrm{Cu}^{2+}, \mathrm{Zn}^{2+}$ and $\mathrm{Hg}^{2+}$ acted as inhibitors of enzymatic activity. $\mathrm{Mg}^{2+}, \mathrm{Mn}^{2+}$ and $\mathrm{Fe}^{3+}$ had no effect. Similar behavior was observed by these ions at a concentration $10 \mathrm{mM}$.

After dialysis, activation was observed by $\mathrm{Mn}^{2+}(50 \%)$ and by $\mathrm{Fe}^{2+}$ plus dithiothreitol (DTT) $(70 \%)$, but the original activity was not recupered.

D-serine, L-threonine and glycine, were competitive inhibitors of L-serine dehydratase activity, while L-cysteine (fig. 6) acted as a non-competitive inhibitor (table 2).

P-chloromercuribenzoate (PCMB) was a potent inhibitor of the enzymatic activity (table 3). In the presence of $2 \mathrm{mM}$ inhibitor, the activity decreased $75 \%$.

TABLE 2

Effect of substrate analogues on L-serine dehydratase activity

Effet des analogues du substrat sur l'activité L-sérine déshydratase

\begin{tabular}{c|c|c}
\hline Inhibition & Inhibition-type & $\mathrm{Ki}(\mathrm{mM})$ \\
\hline D-serine & competitive & 30 \\
L-threonine & competitive & 2 \\
glycine & competitive & 20 \\
L-cysteine & non-competitive & 8 \\
\hline
\end{tabular}

TABLE 3

Effect of PCMB on L-serine dehydratase activity

Effet du PCMB sur l'activité L-sérine déshydratase

\begin{tabular}{c|c}
\hline PCMB $(\mathrm{mM})^{(\mathrm{a})}$ & ${\text { Specific } \text { activity }^{(\mathrm{b})}}^{\text {PC }^{2}}$ \\
0.5 & 82.5 \\
1 & 80.0 \\
2 & 49.5 \\
4 & 24.7 \\
& 12.7 \\
\hline
\end{tabular}

(a) p-chloromercuribenzoate.

(b) nmoles of pyruvate/min $/ \mathrm{mg}$ of protein. 


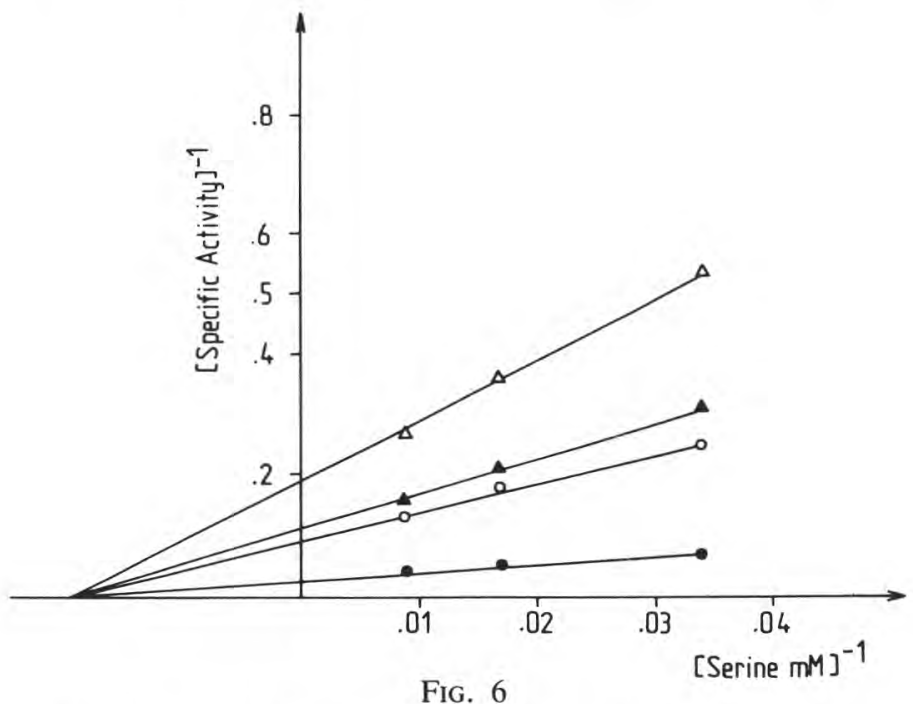

Inhibition of L-serine dehydratase activity by L-cysteine. L-cysteine concentration: $\longrightarrow 0 ; \bigcirc-12.5 \mathrm{mM}$; $\triangle \longrightarrow, 25 \mathrm{mM} ; \triangle \longrightarrow, 50 \mathrm{mM}$.

Inhibition de l'activité L-sérine déshydratase par la L-cystéine. Concentration de la L-cystéine: 0,$0 ; 0$ O, $12,5 \mathrm{mM}$; $\triangle \longrightarrow, 25 \mathrm{mM} ; \triangle \longrightarrow 50 \mathrm{mM}$.

\section{Discussion}

L-serine dehydratase is present in cell-free extract of $S$. faecalis, and it is specific for L-serine.

This is a Michaelis type enzyme as serine dehydratases from Clostridium acidiurici (BEnziman et al., 1960), Brevibacterium linens (Hamouy and DesmaZEAUD, 1985), and Lactobacillus murinus (FARIAS et al., 1985).

The apparent $\mathrm{Km}(50 \mathrm{mM})$ is not exceptional; the same value was reported for the enzyme from B. linens (Hamouy and Desmazeaud, 1985); the enzyme from other species such as Pseudomonas cepacia (WoNG and Lessie, 1979), Escherichia coli $\mathrm{K}_{12}$ (NEWMAN and KAPOOR, 1980) and Lactobacillus murinus (FARIAS et al., 1985) has a $\mathrm{Km}$ value of same order of magnitude, $2 \times 10^{-2} \mathrm{M} ; 42 \times 10^{-2} \mathrm{M}$, and $83.3 \times 10^{-2} \mathrm{M}$, respectively. Similar values were reported for L-serine dehydratase from eukaryotes (SUDA and Nakagawa, 1971 ; Selim and Greenberg, 1959).

The optimum $\mathrm{pH}$ for L-serine dehydratase is generally slightly alkaline. The value obtained for $S$. faecalis enzyme was in agreement with those reported for L-serine dehydratase from Corynebacterium (MoRIKAwa et al., 1974) ; Cl. acidiurici (SAgERS and CARTER, 1971) ; Klebsiella aerogenes (VINING and Magasanik, 1981), and $P$. cepacia (Wong and Lessie, 1979). 
The $\mathrm{pH}$ value was lower than that obtained for B. linens (Hamour and Desmazeaud, 1985) and higher than that reported for L. murinus (Farias et al., 1985).

The two last enzymes, are thermolabile proteins; same behavior was observed in $S$. faecalis enzyme. However, L-serine dehydratase from $S$. faecalis was very stable during storage at $-70{ }^{\circ} \mathrm{C}$.

Usually, serine dehydratase enzymes are very sensible to procedures such as dialysis or dilution. The enzyme from $S$. faecalis was not an exception.

The non-competitive inhibition by L-cysteine is interesting since this aminoacid is generally cited as a competitive inhibitor of the enzyme (ALFOLDI et al., 1968 ; Suda and Nakagawa, 1971 ; Morikawa et al., 1974 ; Gannon et al., 1977).

This behavior was only observed in $B$. linens (Hamouy and Desmazeaud, 1985). L-cysteine would act as a chelator. Inhibition produced by L-cysteine, $\mathrm{HgCl}_{2}$ and PCMB would by tend to show that a metal ion, probably $\mathrm{Fe}^{2+}$ participates in the enzymatic catalysis; this has been shown in other cases (Benziman et al., 1960 ; Carter and Sagers, 1972; Newman and Kapoor, 1980 ; Hamouy and Desmazeaud, 1985). In addition $\mathrm{Fe}^{2+}$ is absolutely necessary for L-serine dehydratase activity in $\mathrm{Cl}$. acidiurici (CARTER and SAGERS, 1972). $\mathrm{Fe}^{2+}$ stimulated L-serine dehydratase activity from $S$. faecalis, after dialysis, slight reactivation was obtained by $\mathrm{Fe}^{2+}$ in the presence of DTT.

D-serine, glycine and L-threonine acted as a competitive inhibitors. This behavior is in accordance with the chemical structures of these aminoacids.

PLP has no effect on the enzymatic activity. This was observed too in $\mathrm{Cl}$. acidiurici (SAGERS and CARTER, 1971) and in Arthrobacter globiformis (GANNON et al., 1977). This cofactor cannot reactivate the enzyme after dialysis as was observed too in $B$. linens (Hamouy and Desmazeaud, 1985). The most interesting finding reported here is the first description of L-serine dehydratase activity exhibited by bacteria of the genus Streptococcus.

Reçu le 11 mars 1987. Accepté pour publication le 12 octobre 1987.

\section{Acknowledgements}

This work was partially supported by grants from Secretaría de Ciencia y Tecnología, Argentina, 1984-1985. 


\section{References}

Alfoldi L., Rasko I., Kerekes E., 1968. L-serine deaminase of Escherichia coli. J. Bacteriol., 96, 1512-1518.

Benziman M., Sagers R.D., Gunsalus I.C., 1960. L-serine specific dehydratase from Clostridium acidiurici. J. Bacteriol., 79, 474-478.

Bridgeland E.S., Jones K.M., 1965. L-serine dehydratase of Arthrobacter globiformis. Biochem. J., 94, 1-24.

CARTER J.E., SAgers R.D., 1972. Ferrous ion-dependent L-serine dehydratase from Clostridium acidiurici. J. Bacteriol., 109, 757-763.

Dumont J.P., AdDA J., 1978. Flavour formation in dairy products. In : Progress in Flavour research. Ed. Lang D.G. and Nurstein H.E., London Applied Sciences Publishers, 245-262.

Farias M.E., Strasser de SaAd A.M., Pesce de Ruiz Holgado A., Oliver G., 1985. Evidence for the presence of L-serine dehydratase in Lactobacillus murinus. J. Gen. Appl. Microbiol., $31,563-567$.

Friedemann T.E., Haugen G.E., 1943. The determination of Keto-acids in blood and urine. $J$. Biol. Chem., 147, 415-422.

Gale E.F., Stephenson M., 1938. Factors influencing the activity of DL-serine deaminase in Bacterium coli. J. Biol. Chem., 32, 392-404.

Gannon F., Bridgeland E.S., Jones K.M., 1977. L-serine dehydratase from Arthrobacter globiformis, Biochem. J., 161, 345-355.

GRIFFITHS S.K., DE Moss R.D., 1970. Physiological comparison of L-serine dehydratase and tryptophanase from Bacillus alvei. J. Bacteriol., 101, 813-820.

Hamouy D., 1983. Etude du catabolisme de la sérine chez Brevibacterium linens. Thèse, Université Paris XI.

Hamouy D., Desmazeaud M.J., 1985. Characterization of an L-serine dehydratase activity in permeabilized cells of Brevibacterium linens ATCC 9175. Lait, 65, 103-121.

Isenberg S., Newman E.B., 1974. Studies on L-serine deaminase of Escherichia coli $\mathrm{K}_{12} . J$. Bacteriol, $118,53-58$.

Kosikowskı F., 1978. In cheese and Fermented Milk Foods. 2nd edition. New York, Kosikowski F.V. and Associates, 16-48, 179-212, 228-260, 413-446.

Lowry O.H., Rosebrough N.J., Farr A.L., Randall R., 1951. Protein measurement with the folin phenol reagent. J. Biol. Chem., 193, 265-275.

Morikawa Y., Nakamura N., Kimura K., 1974. Purification and some properties of L-serine dehydratase of Corynebacterium sp. Agric. Biol. Chem., 38, 531-537.

NeWman E.B., KAPOOR V., 1980. In vitro studies on L-serine deaminase activity of Escherichia coli $\mathrm{K}_{12}$. Can. J. Biochem., 58, 1292-1297.

Raibaud P., Dickinson A.B., Sacquet E., Charlier H., Mocquot G., 1966. La microflore du tube digestif du rat. I. Techniques d'étude et milieux de culture proposés. Ann. Microbiol., $110,568-590$.

Rasko I., Kerekes E., Alfoldi L., 1969. Properties of L-serine deaminase from Salmonella typhimurium and Bacillius cereus. Acta Microbiol. Hung., 16, 237-244.

SAgers R.D., Carter J.E., 1971. L-serine dehydratase (Clostridium acidiurici). In : Methods in Enzymology, XVII (B). Ed. Tabor H. and Tabor C.W., New York, Academic Press, 351-356.

Selim A.S.M., Greenberg D.M., 1959. An enzyme that synthesizes cystathionine and deaminates L-serine. J. Biol. Chem., 234, 1474-1480.

SudA M., NAKagawa H., 1971. L-serine dehydratase (rat liver). In : Methods in Enzymology, XVII (B). Ed. Tabor H. and Tabor C.W., New York Academic Press, 346-351.

Vining L.C., MAGasanik B., 1981. Serine utilization by Klebsiella aerogenes. J. Bacteriol., 146, 647-655.

Wong H.C., Lessie T.G., 1979. Hydroxyaminoacid metabolism in Pseudomonas cepacia : role of L-serine deaminase in dissimilation of serine, glycine and threonine. J. Bacteriol., 140, 240245. 